\title{
Manajemen Pemupukan Kelapa Sawit di Sungai Bahaur Estate, Kalimantan Tengah
}

The Manajement of Palm Oil Fertilizing at Sugai Bahaur Estate, Central of Kalimantan

\author{
Aslina Putri Nunyai, Sofyan Zaman*, dan Sudirman Yahya \\ Departemen Agronomi dan Hortikultura, Fakultas Pertanian, Institut Pertanian Bogor (Bogor Agricultural \\ University), Jl. Meranti, Kampus IPB Darmaga, Bogor 16680, Indonesia \\ Telp.\&Faks. 62-251-8629353 e-mail agronipb@indo.net.id \\ *Penulis Korespondensi: sofyan_zaman@yahoo.co.id \\ Disetujui 4 Mei 2016/ Published online 9 Mei 2016
}

\begin{abstract}
The Increasing of world vegetable oil is required, and it needs an effort to increase the quantity and quality of oil crop production. Elaeis guineensis Jacq. is one of the palmae plant which produce the biggest volume of vegetable oil in the world. The optimal palm oil growth will produce a lot of fresh fruit bunch by high quality oil. The good cultivation will effect the high quality of fruit bunch output, and one of the important cultivation is fertilizing. The purphose of internship program is to study about management of plantation in all cultivate consists maintanance and harvesting which conducted during 4 months. The methode of internship program consists technic and management aspects. The specific aspect is about fertilizing management which is known as 4 right fertilizing concept (4T) that consist: type, dosage, time, methode and place. The results show that the time concept has not applied well and still needs effort to improve the quality of human performance and better facilities for efectivity and eficiency of fertilization.
\end{abstract}

Keywords: fertilization, fresh fruit bunch, human performance

\begin{abstract}
ABSTRAK
Kebutuhan minyak nabati yang terus meningkat menyebabkan perlu adanya peningkatan kuantitas dan kualitas minyak nabati dunia. Elaeis guineensis Jacq. merupakan tanaman jenis palma penghasil minyak nabati terbanyak didunia. Kelapa sawit yang tumbuh optimal akan menghasilkan tandan buah yang segar dan minyak yang berkualitas. Budidaya yang tepat mempengaruhi hasil tandan buah segar (TBS) dan salah satu budidaya yang penting adalah pemupukan. Tujuan dilaksanakan kegiatan magang adalah untuk mempelajari kegiatan pengelolaan kebun mulai dari perawatan hingga panen yang dilakukan selama 4 bulan. Metode pelaksanaan magang terdiri dari aspek teknis dan manajerial. Aspek khusus pengamatan manajemen pemupukan konsep 4 tepat pemupukan (4T) yaitu tepat jenis, dosis, waktu, cara, dan tempat. Hasil pengamatan menunjukkan bahwa konsep tepat waktu belum terlaksana dengan baik dan masih perlu dilakukan upaya peningkatan kualitas tenaga kerja serta fasilitas yang lebih baik agar pelaksanaan pemupukan efektif dan efisien.
\end{abstract}

Kata kunci: pemupukan, tandan buah segar, tenaga kerja 


\section{PENDAHULUAN}

Elaeis guineensis Jacq. merupakan tanaman jenis palma penghasil minyak nabati yang digunakan untuk tujuan komersil dalam berbagai bidang industri, seperti: makanan, kosmetika, sabun dan sumber energi biodiesel. Kebutuhan minyak nabati akan terus meningkat sebagai akibat pertumbuhan penduduk dan peningkatan pendapatan domestik bruto (Pahan, 2010). Produksi kelapa sawit di Indonesia produksi tertinggi dibandingkan komoditas perkebunan lainnya, saat ini produksi kelapa sawit Indonesia mencapai 14.8 juta ton (BPS, 2012). Indonesia merupakan salah satu penghasil komoditas kelapa sawit terbesar di dunia, dengan luas areal dan produksi kelapa sawit seluas 9.07 juta ha dengan produksi 7.26 juta ton CPO pada tahun 2012 yang tersebar di seluruh provinsi di Indonesian (Ditjenbun, 2013).

Tanaman kelapa sawit memilki siklus hidup produktif yang panjang yaitu 25-30 tahun. Pertumbuhan tanaman ini dipengaruhi oleh ketersediaan unsur hara secara terus menerus. Ketersediaan unsur hara yang disediakan oleh tanah sangat terbatas, perlu adanya penambahan unsur hara dari luar untuk memenuhi kebutuhan unsur hara tanaman kelapa sawit. Salah satu upaya untuk melengkapi kebutuhan unsur hara kelapa sawit yaitu dengan pemberian pupuk yang efektif dan efisien. Pemupukan yang tepat adalah yang memperhatikan ketepatan dosis,jenis, waktu,cara, dan harga (Winarna et al., 2003). Pemupukan sangat bermanfaat untuk meningkatkan kesuburan serta meningkatkan daya tahan tanaman terhadap serangan penyakit dan pengaruh iklim yang tidak menguntungkan (Pahan, 2010).

Biaya yang dikeluarkan oleh perusahaan untuk pemupukan berkisar $40-60 \%$ dari seluruh total biaya pemeliharaan tanaman secara keseluruhan sehingga harus diikuti dengan cara pemupukan yang baik agar produksi tinggi tercapai (Sastrosayono, 2003). Pengawasan pupuk meliputi manajemen ketepatan jenis, dosis, waktu, cara, dan tempat. Aplikasi pemupukan di atas dosis akan berpengaruh negatif terhadap produksi atau menimbulkan kerugian ekonomi. Penggunaan pupuk kimia yang berlebihan juga berdampak buruk bagi lingkungan sekitar karena dapat merusak keseimbangan ekologi.

Kegiatan magang yang dilaksanakan mempunyai dua tujuan yaitu tujuan umum dan tujuan khusus. Tujuan umum dilakukannya magang ini adalah: meningkatkan pengetahuan mahasiswa dan membentuk sikap serta keterampilan kerja, melatih kemampuan mahasiswa agar dapat bekerja secara profesional di bidang perkebunan kelapa sawit, meningkatkan softskill agar mampu mempersiapkan diri memasuki dunia kerja. Tujuan khusus untuk memperoleh ilmu terkait keefektifan dan efisiensi pemupukan kelapa sawit, serta mampu mengatasi masalah yang berkaitan dengan kualitas pemupukan.

\section{BAHAN DAN METODE}

Kegiatan magang ini dilaksanakan pada tanggal 9 Februari hingga 9 Juni 2013 di Kebun Sungai Bahaur Estate (SBHE), Desa Pelataran, Kecamatan Cempaga Hulu, Kabupaten Kota Waringin Timur, Kalimantan Tengah. Pelaksanaan kegiatan magang terdiri atas dua aspek yaitu aspek teknis dan manajerial.Aspek teknis pelaksanaan magang yaitu penulis diposisikan sebagai karyawan harian lepas selama satu bulan pertama. Pada aspek ini penulis melakukan seluruh kegiatan yang berkaitan dengan perawatan dan pemanenan kebun. Kegiatan yang dilakukan antara lain pengendalian gulma, pengendalian hama terpadu, pemupukan, pemanenan, dan kegiatan pengelolaan limbah.Aspek manajerial dipelaksanaan magang yaitu penulis diposisikan sebagai pendamping mandor pada bulan kedua dan pendamping asisten kebun pada bulan ketiga dan keempat. Pada posisi sebagai pendamping mandor, penulis mempelajari kewenangan dan tanggungjawab sebagai seorang mandor tentang pengawasan dan koordinasi tenaga kerja yang dilakukan di kebun. Sebagai pendamping Asisten Divisi, penulis akan belajar cara-cara manajerial tingkat divisi, misalnya menyusun rencana kerja Divisi, melaksanakan rencana kerja yang telah disusun, mengawasi pelaksanaan pekerjaan yang telah dijadwalkan, dan mengevaluasi pekerjaan yang telah dilaksanakan.

Pelaksanaan kegiatan magang secara khusus diarahkan pada aspek pengamatan tentang manajemen pemupukan kelapa sawit yaitu dengan cara mengikuti seluruh rangkaian kegiatan yang berkaitan dengan pemupukan dan analisis seluruh proses manajemen distribusi pupuk dari gudang penyimpanan pupuk hingga diaplikasikan ke lahan. Penulis juga mempelajari tentang pengelolaan analisis daun, rekomendasi pemupukan, pengawasan tenaga kerja dan kegiatan pemupukan. Perolehan informasi juga diperoleh dengan cara melakukan wawancara pada beberapa staf dan karyawan di kebun terkait manajemen pemupukan. Pengumpulan data 
dilakukan dengan menggunakan metode langsung (data primer) dan metode tidak langsung (data sekunder). Data primer adalah informasi yang diperoleh langsung melalui pengamatan di lapangan maupun wawancara dengan karyawan, mandor dan asisten kebun.Beberapa indikator yang diamati oleh penulis adalah variabel yang terkait dengan manajemen pemupukan yang efektif dan efisien di kebun. Data primer yang telah diperoleh dibandingkan dengan standar yang ada di perusahaan. Data primer yang berkaitan dengan pengamatan antara lain: ketepatan (dosis, jenis, waktu,cara dan tempat), tenaga kerja, gejala defisiensi, dan manajemen distribusi pupuk di kebun. Data sekunder yang diperoleh yaitu: kondisi umum, standar target kebun, organisasi, dan prasarana kebun. Data yang diperoleh di kebun akan diolah dengan metode kualitatif dan kuantitatif. Analisis kualitatif yaitu dengan menjabarkan seluruh informasi dan data yang telah diperoleh, kemudian dibandingkan melalui studi pustaka dan literatur. Analisis kuantitatif digunakan untuk mengolah data yang sifatnya numerik, seperti: nilai rata-rata dan persentase.

\section{HASIL DAN PEMBAHASAN}

\section{Konsep Pemupukan}

Aplikasi pemupukan di lahan pada dasarnya untuk menambah ketersediaan unsur hara yang berkurang atau hilang akibat penyerapan hara terus menerus oleh tanaman.Tanaman membutuhkan unsur hara dalam jumlah yang besar. Menurut Darmosarkoro et al. (2005) dalam setiap ton TBS mengandung hara yang setara dengan $6.3 \mathrm{~kg}$ Urea, $2.1 \mathrm{~kg}$ TSP, $7.3 \mathrm{~kg} \mathrm{KCL}$ dan $4.9 \mathrm{~kg}$ Kieserite, hara tersebut harus dikembalikan dalam bentuk pupuk sehingga untuk menjamin ketersediaannya perlu upaya manajemen pemupukan yang tepat. Manajemen pemupukan dilakukan berdasarkan prinsip keefektifan dan efisiensi pemupukan.Keefektifan pemupukan memastikan pupuk yang diaplikasikan terserap cepat oleh akar tanaman dan menekan losses pupuk.Efisiensi berkaitan dengan manajemen biaya yang dikeluarkan oleh kebun terhadap hasil produksi yang diperoleh.

Menurut Sastrosayono (2003) biaya yang dikeluarkan oleh perusahaan untuk pemupukan berkisar $40-60 \%$ dari seluruh total biaya pemeliharaan tanaman secara keseluruhan sehingga harus diikuti dengan cara pemupukan yang baik agar produksi tinggi tercapai. Keberhasilan keefektifan dan efisiensi pemupukan dapat tercapai dengan memperhatikan standar operasional konsep ketepatan pemupukan yang memperhatikan konsep empat tepat.

\section{Tepat Jenis}

Penentuan tepat jenis diperoleh dari hasil analisis defisiensi unsur hara secara visual yang penulis amati di lapangan dan disesuaikan dengan data sekunder dari kebun mengenai informasi status unsur hara di kebun pada tahun 2012 untuk menentukan unsur hara yang dibutuhkan tanaman. Berdasarkan data primer defisiensi pupuk secara visual pada Tabel 9 dan status unsur hara kebun SBHE berdasarkan lembaga Riset BGA yang tercantum pada Gambar 1,kemudian diamati kandungan unsur hara pada jenis-jenis pupuk yang diaplikasikan ke lahan telah sesuai dengan kebutuhan unsur hara tanaman atau tidak sesuai.

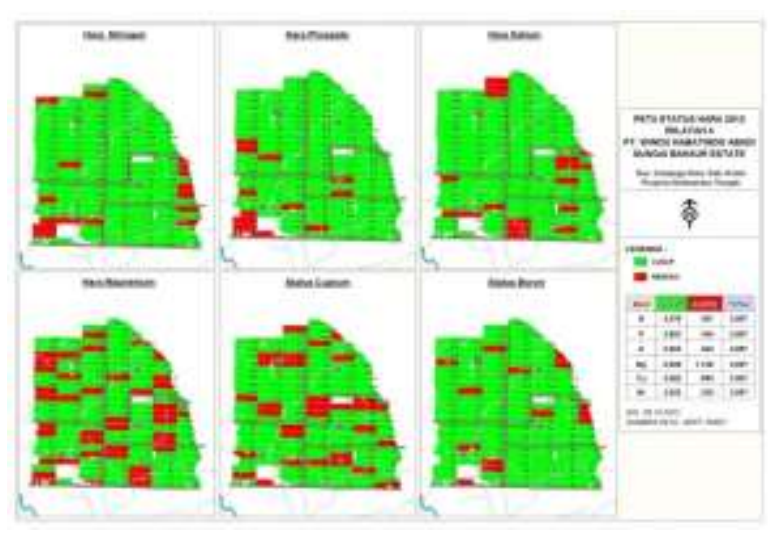

Gambar 1. Status unsur hara kebun SBHE

Pengamatan terhadap defisiensi unsur hara secara visual menunjukkan bahwa masih banyak pokok kelapa sawit yang mengalami defisiensi unsur hara $\mathrm{N}, \mathrm{P}, \mathrm{K}, \mathrm{Mg}$, dan $\mathrm{B}$. Hal ini juga ditunjukkan pada kondisi status unsur hara kebun tahun 2012 dari Departemen Riset BGA yang menunjukkan bahwa di kebun SBHE masih terdapat banyak tanaman yang mengalami defisiensi unsur hara $\mathrm{N}, \mathrm{P}, \mathrm{K}, \mathrm{Mg}, \mathrm{B}$ dan juga $\mathrm{Cu}$ yang tidak penulis amati secara visual. Jenis pupuk yang diaplikasikan di kebun SBHE antara lain pupuk Rock phosphate (RP), HGFB, Urea, NPK, MOP, dolomite, Kieserite, dan Chelated zincopper. Berikut Tabel 1 mengenai kandungan unsur hara pada beberapa jenis pupuk.

Tabel 1 . Nama pupuk dan kandungan unsur hara

\begin{tabular}{lc}
\hline Nama pupuk & Kandungan hara \\
\hline Urea & $\mathrm{N}$ \\
Rock phosphat (RP) & $\mathrm{P}$ \\
MOP & $\mathrm{K}$ \\
Dolomit & $\mathrm{Mg}, \mathrm{Ca}$ \\
HGFB & $\mathrm{B}$ \\
Kieserite & $\mathrm{Mg}$ \\
NPK & $\mathrm{N}, \mathrm{P}, \mathrm{K}$ \\
Chelated zincopper & $\mathrm{Zn}, \mathrm{Cu}$ \\
\hline Sumber:
\end{tabular}


Kandungan unsur hara pada jenis pupuk yang diaplikasikan di lahan hampir seluruhnya telah memenuhi kebutuhan tanaman sesuai konsep tepat jenis, namun beberapa jenis pupuk seperti pupuk NPK dan Dolomit memiliki kandungan yang sama pada pupuk yang telah diaplikasikan, seperti: pupuk NPK yang kandungan unsur haranya sama dengan pupuk Urea, RP, dan MOP. Pupuk Dolomit dan Kieserite juga memiliki kandungan sama yaitu magnesium, hal ini dapat terjadi karena ketersediaan pupuk yang ada di gudang central. Konsep tepat jenis telah tepat diaplikasikan sesuai dengan kebutuhan tanaman.

\section{Tepat Dosis}

Ketepatan dosis pada dasarnya adalah memperhatikan keseimbangan asupan unsur hara yang dibutuhkan tanaman. Defisiensi unsur mengakibatkan terhambatnya pertumbuhan tanaman kelapa sawit dan penurunan kualitas buah, apabila berlebihan tanaman dapat mengalami plasmolisis dan pencemaran lingkungan. Pertimbangan yang digunakan dalam penentuan dosis pupuk adalah hasil analisis daun dan tanah, realisasi produksi lima tahun sebelumnya, realisasi pemupukan sebelumnya, data curah hujan lima tahun sebelumnya, dan hasil pengamatan di lapangan seperti gejala defisiensi hara (Winarna et al., 2003).

Ketepatan dosis yang diamati penulis meliputi ketepatan dosis untilan dan aplikasi penaburan pupuk di lahan. Pengamatan dosis untilan MOP dan Ureadapat dilihat pada Tabel 2 dan Tabel 3. Tabel tersebut menunjukkan nilai ketepatan bobot untilan pupuk MOP yaitu 97.08\%danpupuk Urea adalah 95\%. Nilai ini telah mencapai standar kebun $\geq 95 \%$ yang menunjukkan bahwa dosis untilan telah tepat.Penguntil telah mampu menguntil berbagai jenis pupuk dengan tepat dan losses rendah. Prestasi tenaga kerja penguntil sangat baik, rata- rata penguntil dapat menyelesaikan untilan $2500 \mathrm{~kg} / \mathrm{HK}$ dengan standar prestasi kerja $2000 \mathrm{~kg} / \mathrm{HK}$ apabila lebih dari basis maka penguntil mendapatkan premi sesuai dengan tonase. Hal ini efisien karena ketersediaan pupuk di gudang selalu tersedia sehingga kegiatan pemupukan berjalan dengan lancar.

Tabel 2. Ketepatan dosis untilan pupuk MOP

\begin{tabular}{cccc}
\hline $\begin{array}{c}\sum \mathrm{TK} \\
(\text { Orang })\end{array}$ & $\begin{array}{c}\text { Bobot/untilan } \\
(\mathrm{kg})\end{array}$ & $\begin{array}{c}\text { Bobot } \\
\text { rataan }(\mathrm{kg})\end{array}$ & $\begin{array}{c}\text { Ketepatan dosis } \\
(\%)\end{array}$ \\
\hline 5 & 15 & 14.5 & 96.7 \\
5 & 15 & 14.8 & 98.7 \\
5 & 15 & 14.4 & 96.0 \\
5 & 15 & 14.3 & 95.3 \\
5 & 15 & 14.8 & 98.7 \\
\hline \multicolumn{3}{c}{$14.56 \pm 0.23$} & 97.08 \\
\hline Rata-rata &
\end{tabular}

Sumber: Hasil pengamatan lapangan (2013)

Tabel 3. Ketepatan dosis untilan pupuk urea

\begin{tabular}{cccc}
\hline $\begin{array}{c}\sum \mathrm{TK} \\
\text { (orang) }\end{array}$ & $\begin{array}{c}\text { Bobot/untilan } \\
(\mathrm{kg})\end{array}$ & $\begin{array}{c}\text { Bobot } \\
\text { rataan }(\mathrm{kg})\end{array}$ & $\begin{array}{c}\text { Ketepatan dosis } \\
(\%)\end{array}$ \\
\hline 5 & 12 & 11.2 & 93.3 \\
5 & 12 & 11.6 & 96.7 \\
5 & 12 & 11.4 & 95 \\
5 & 12 & 11.1 & 92.5 \\
5 & 12 & 11.7 & 97.5 \\
\hline Rata-rata & & $11.4 \pm 0.25$ & 95 \\
\hline
\end{tabular}

Penulis mengamati jumlah takaran mangkuk yang dikalibrasi dengan dosis yang dibutuhkan, misalnya dosis MOP yang diperlukan adalah $1.8 \mathrm{~kg}$, untuk 1 takaran mangkuk bobotnya adalah $0.6 \mathrm{~kg}$ sehingga untuk tiap pokok diaplikasikan 3 takaran mangkuk untuk mencapai bobot $1.8 \mathrm{~kg}$. Pengamatan ketepatan dosis penaburan pupuk MOP dapat dilihat pada Tabel 4.

Tabel 4. Ketepatan dosis pupuk MOP di lapangan

\begin{tabular}{cccccc}
\hline Blok/ulangan & $\begin{array}{c}\text { P Pokok diamati } \\
\text { (pohon) }\end{array}$ & $\begin{array}{c}\text { Dosis/ } \\
\text { pokok }(\mathrm{kg})\end{array}$ & $\begin{array}{c}\text { Dosis tidak sesuai } \\
\text { (pohon) }\end{array}$ & $\begin{array}{c}\text { \% Dosis tidak } \\
\text { sesuai }\end{array}$ & \% Tepat dosis \\
\hline 1 & 110 & 1.75 & 20 & 18 & 82 \\
2 & 100 & 1.75 & 8 & 8 & 92 \\
3 & 115 & 1.75 & 25 & 22 & 78 \\
\hline Rata-rata & 325 & & $17.67 \pm 8.7$ & 16 & 84 \\
\hline
\end{tabular}

Sumber: Hasil pengamatan lapangan (2013)

Persentase yang tidak sesuai dengan dosis adalah $17.67 \%$, sedangkan persentase tepat dosis adalah $84 \%$. Tenaga penabur pupuk telah cukup baik namun masih dibawah standar prestasi kebun. Hal- hal yang dapat menyebabkan ketidakefektifan dosis pupuk karena beberapa penabur masih belum memahami tentang bobot takaran yang digunakan pada jenis pupuk tertentu, padahal takaran yang disediakan kebun terdiri dari tiga jenis: yaitu takaran ukuran $0.6 \mathrm{~kg}$, $0.4 \mathrm{~kg}$, dan $0.02 \mathrm{~kg}$. Takaran pupuk digunakan sesuai dengan jenis pupuk yang dosisnya berbeda, untuk pupuk MOP dengan dosis $1.75 \mathrm{~kg}$ menggunakan takaran $0.6 \mathrm{~kg}$ sebanyak 3 kali. 
Takaran untuk pupuk RP, Urea, dan Kieserite menggunakan takaran $0.4 \mathrm{~kg}$ sebanyak 2 kali penaburan.Hal ini penting untuk diketahui penabur agar dosis dapat dilakukan dengan baik sehingga kegiatan Field Visit perlu dilakukan untuk kontrol kualitas penaburan pupuk. Berikut Tabel 5 dosis berbagai jenis pupuk.

Tabel 5. Dosis berbagai jenis pupuk

\begin{tabular}{lcc}
\hline \multicolumn{1}{c}{ Jenis pupuk } & $\begin{array}{c}\text { Dosis untilan } \\
(\mathrm{kg})\end{array}$ & $\begin{array}{c}\text { Dosis/pokok } \\
(\mathrm{kg})\end{array}$ \\
\hline Urea & 12 & 0.75 \\
Rock Phosphate & 12 & 0.75 \\
MOP & 14 & 1.75 \\
Dolomit & 10 & 1.25 \\
Kieserite & 13.6 & 0.8 \\
\hline
\end{tabular}

Sumber: Hasil pengamatan lapangan (2013)

Pengamatan di lapangan menunjukkan bahwa tenaga penabur telah memenuhi kriteria tepat dosis.Namun belum seluruh penabur belum memahami secara tepat konsep tepat dosis yang sebenarnya. Sebagian besar penabur mengacu pada prestasi jumlah output pupuk yang diaplikasikan dalam 1 hari kerja, tetapi masih ada beberapa penabur yang memperhatikan ketepatan dosis pupuk, hal ini menunjukkan aplikasi pemupukan masih dipengaruhi faktor subjektivitas.

\section{Tepat Waktu}

Aplikasi pemupukan di kebun SBHE terbagi atas dua semester yaitu semester I (Januari-Juni) dan Semester II (Juli-Desember) dapat lihat pada Tabel 6. Pembagian semester ini bertujuan agar manajemen rotasi pupuk dapat terlaksana dengan efektif dan efisien.Tujuan pembagian semester juga untuk menghindari beberapa jenis pupuk yang sifatnya antagonis apabila diaplikasikan pada waktu yang bersamaan atau berdekatan.Waktu yang dibutuhkan tanaman untuk menyerap pupuk secara optimal yaitu pada saat 2 bulan setelah aplikasi sehingga manajemen waktu sangat diperlukan untuk memastikan pupuk terserap efektif. Berikut tabel yang menunjukkan waktu rencana dan aplikasi pemupukan.

Tabel 6. Rencana dan aplikasi pemupukan kebun SBHE 2013

\begin{tabular}{|c|c|c|c|c|c|c|c|c|c|c|c|c|}
\hline \multirow{2}{*}{ Jenis Pupuk } & \multicolumn{12}{|c|}{ Bulan aplikasi dan realisasi pupuk kebun SBHE } \\
\hline & Jan & Feb & Mar & Apr & Mei & Jun & Jul & Agt & Sep & Okt & Nov & Des \\
\hline $\mathrm{RP}$ & R1 & A1 & & & & & & & & & & \\
\hline HGFB & & R1 & A1 & & & & R2 & & & & & \\
\hline Urea & & & & A1 & 21 & & & & R2 & & & \\
\hline MOP & & & A1 & & 21 & & & & R2 & & & \\
\hline Dolomit & & & & & & R1 & A1 & & & & & \\
\hline Kieserite & & & R1 & & $\mathrm{A1}$ & & & & & & & \\
\hline C. Zinc & & $\mathrm{R} 1$ & & & & & & & & & & \\
\hline
\end{tabular}

Keterangan: $(\mathrm{P} 1=$ rencana rotasi $1 ; \mathrm{P} 2=$ rencana rotasi $2 ; \mathrm{A} 1=$ aplikasi rotasi 1$)$ warna orange : waktu rencana pemupukan; warna merah: waktu realisasi pemupukan; warna hijau: waktu rencana dan aplikasi yang sama

Tabel 6 menunjukkan bahwa pelaksanaan aplikasi pupuk tidak selalu sama dengan waktu yang direncanakan, hal ini dipengaruhi oleh ketersediaan jenis pupuk yang ada di gudang central. Pemupukan dipengaruhi oleh kondisi cuaca dan curah hujan. Pagi sampai siang hari adalah waktu yang tepat untuk aplikasi pemupukan kelapa sawit (Pahan 2008). Pelaksanaan kegiatan pemupukan di kebun SBHE dilaksanakan mulai dari pukul 06.00 pagi hingga pukul 12.00 siang dan apabila hari hujan maka kegiatan pupuk dialihkan ke kegiatan perawatan tebas manual. Kenyataan di lapangan meskipun hari hujan terkadang kegiatan pemupukan tetap dilaksanakan. Oleh karena itu, data mengenai curah hujan sangat penting untuk menentukan rencana waktu pemupukan.
Darmosarkoro et al. (2005) adalah pemupukan yang dilakukan pada saat (bulan-bulan) dengan curah hujan 100-200 mm/bulan, sedangkan curah hujan minimum $60 \mathrm{~mm} / \mathrm{bulam}$ dan maksimum $300 \mathrm{~mm} /$ bulan. Pahan (2010) menambahkan pada kondisi seperti ini tanah cukup basah (tetapi belum jenuh), sehingga memudahkan terserapnya unsur hara. Kondisi curah hujan kebun SBHE pada bulan Januari-April tahun 2013 dapat dilihat pada Gambar 2.

Berdasarkan data tersebut, kondisi curah hujan tergolong sangat tinggi. Kondisi seperti ini seharusnya tidak dilakukan kegiatan pemupukan karena akan mengakibatkan unsur hara hilang terbawa aliran air (run-off), pupuk yang terbawa air akan terbuang sia-sia dan dapat mengakibatkan pencemaran lingkungan khususnya ekosistem air. 


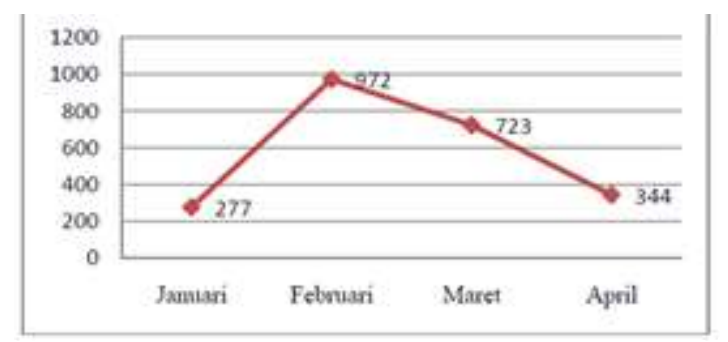

Gambar 2. Curah hujan SBHE Bulan JanuariApril 2013

Waktu pemupukan yang tepat seharusnya dilakukan saat menjelang musim hujan dan akhir musim hujan, namun pada kenyataannya pada Tabel 6 menunjukkan bahwa kegiatan pemupukan dilaksanakan setiap bulan tanpa memperhatikan kondisi curah hujan. Konsep tepat waktu tidak terlaksana dengan baik, hal ini perlu diperhatikan oleh pihak kebun mengingat biaya yang dikeluarkan untuk pemupukan sangat tinggi. Pemupukan yang tepat waktu akan meningkatkan keefektifan penyerapan unsur hara dan efisiensi biaya.

\section{Tepat Cara dan Tempat}

Aplikasi pupuk kebun SBHE terdiri dari metode tebar dan benam.Metode tebar dilakukan pada seluruh jenis pupuk makro, sedangkan metode benam pada pupuk mikro. Pengamatan terhadap ketepatan cara pemupukan pupuk Urea dapat dilihat pada Gambar 2. Persentase ketepatan cara pemupukan sebesar $90.3 \%$, hal ini menunjukkan bahwa penabur telah mengetahui cara aplikasi yang ditebar pada pinggir terluar piringan yang berjarak 1.5-2 $\mathrm{m}$ dari pokok.

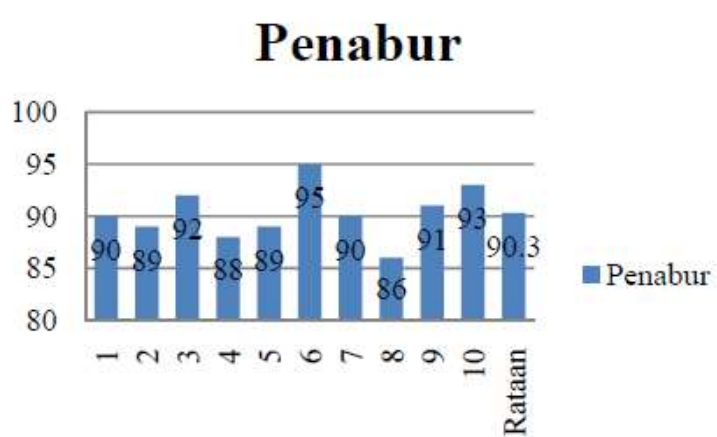

Sumber: Hasil pengamatan lapangan (2013)

Penulis melakukan pengamatan ketepatan tempat pada pupuk RP.Hasil pengamatan dapat dilihat pada Tabel 8. Berdasarkan hasil pengamatan, ketepatan penabur dalam mengaplikasikan pemupukan RP adalah $79 \%$ prestasi ini cukup baik namun masih perlu ditingkatkan karena belum mencapai standar kebun yaitu 90\%. Aplikasi tempat pupuk RP yang tepat adalah pada rumpukan pelepah. Aplikasi pupuk RP di rumpukan pelepah bertujuan untuk merangsang pertumbuhan akan tersier dan quarter karena pupuk RP adalah jenis pupuk immobil yang aplikasinya harus langsung dekat dengan akar agar lebih efektif terserap oleh akar. Secara keseluruhan pupuk RP hampir seluruhnya terpupuk yaitu $99.5 \%$ namun saat pengamatan berlangsung masih ditemukan 2 pokok yang tidak terpupuk sebesar $0.5 \%$ dari total pengamatan, hal ini sebenarnya tidak boleh dilarang keras oleh pihak kebun namun karena kondisi hanca yang terputus oleh parit sungai yang dalam maka masih diperbolehkan oleh pihak kebun.

Tabel 8. Pengamatan ketepatan tempat pupuk RP

\begin{tabular}{lllllllll}
\hline & & \multicolumn{3}{c}{ Distribusi pupuk } & \multicolumn{3}{c}{ Lokasi penebaran } \\
\cline { 3 - 8 } Ulangan & $\begin{array}{c}\text { Jumlah } \\
\text { pengamatan } \\
\text { (pohon) }\end{array}$ & $\begin{array}{c}\text { Terpupuk } \\
\text { (pohon) }\end{array}$ & $\begin{array}{c}\text { Tidak } \\
\text { trpupuk } \\
\text { (pohon) }\end{array}$ & $\begin{array}{c}\text { Susunan } \\
\text { pelepah }\end{array}$ & $\begin{array}{c}\text { Piringan } \\
\text { (pohon) }\end{array}$ & $\begin{array}{c}\text { Gawangan } \\
\text { (pohon) }\end{array}$ & $\begin{array}{c}\text { Susunan } \\
\text { pelepah } \\
\text { dan } \\
\text { gawangan } \\
\text { (pohon) }\end{array}$ & $\begin{array}{c}\text { Susunan } \\
\text { pelepah } \\
\text { dan } \\
\text { piringan } \\
\text { (pohon }\end{array}$ \\
\hline 1 & 72 & 72 & 0 & 62 & 3 & 4 & 1 & 2 \\
2 & 72 & 71 & 1 & 52 & 2 & 5 & 7 & 6 \\
3 & 72 & 72 & 0 & 57 & 2 & 3 & 3 & 7 \\
& 216 & 215 & 1 & 171 & 7 & 12 & 11 & 15 \\
& 99.5 & 0.5 & 79 & 3.3 & 5.6 & 5.1 & 7 \\
\hline
\end{tabular}

Sumber: Hasil pengamatan lapangan (2013)

\section{Hambatan dan Upaya Peningkatan Keefektifan Pemupukan}

Pelaksanaan kegiatan pemupukan akan berjalan dengan baik apabila didukung oleh penyediaan operasional yang baik. Namun, terkadang ditemukan beberapa hambatan di lapang yang dapat menimbulkan masalah apabila tidak diatasi dengan tepat. Beberapa hambatan yang ditemukan saat kegiatan pemupukan antara lain:

a. Gudang BMS yang belum memadai, gudang ini masih terbuat dari kayu yang terbuka dan belum ada pintu untuk menutupnya ketika 
hari hujan atau terlalu terik. Hal ini dapat menimbulkan masalah karena pupuk dapat mudah mencair saat lembab dan menguap saat panas.Sebaiknya gudang BMS terbuat dari bahan yang dapat melindungi pupuk dari cuaca yang ekstrem.Kemudian dibuat pintu agar dapat mengatur kegiatan keluar dan masuknya pupuk dari gudang.

b. Infrastruktur jalanan di Main Road dan Collection Road yang kurang baik, menyebabkan jalanan rusak dan menghalangi truk untuk melewati lintasan pengeceran pupuk. Hal ini disebabkan karena jalanan terbuat dari tanah laterit yang mudah rusak bila tergenang air. Oleh karena itu perlu manajemen drainase yang baik pada titik-titik rawan banjir. Penimbunan laterit pada jalanan yang rusak juga perlu dilakukan namun laterit tidak hanya ditumpuk tetapi sebaiknya dialasi papan kayu terlebih dahulu agar lebih kuat mengikat laterit. Karung pupuk yang sobek menyebabkan losses pupuk meningkat, perlu adanya upaya pengawasan dan penggantian terhadap karung yang tidak layak pakai.

c. Kalibrasi takaran untilan perlu pengawasan rutin sebab bahan takaran terbuat dari bean plastik yang mudah memuai.

d. Pemahaman tenaga penabur tentang aplikasi pemupukan yang tepat sehingga simulasi pemupukan perlu dilakukan secara rutin.

e. Kondisi hanca yang terputus karena adanya parit sungai atau rawa yang lebar menyulitkan penabur untuk memupuk seluruh pokok, sebaiknya dibuat jembatan sesuai standar pada areal hanca. Piringan yang masih banyak ditumbuhi oleh gulma, hal ini dapat menghambat pemupukan dan mengurangi efisiensi pupuk karena pupuk terbuang percuma bila ditebarkan pada gulma.

f. Kantor BMS yang kurang terawat, sebaiknya kantor diberikan informasi yang berkaitan dengan pupuk dan dijadikan ruang diskusi pupuk sehingga kinerja tim BMS dapat lebih meningkat apabila tim bekerjasama dengan baik.

Hambatan pada kegiatan pemupukan perlu dibenahi agar meningkatkan kualitas pemupukan.Kerjasama dari seluruh pihak sangat diperlukan untuk memfasilitasi penyediaan akses jalan yang memadai, transportasi, supervisi yang baik, tenaga kerja yang berkualitas, sarana dan prasana yang lengkap serta pelaksanaan pemupukan yang sesuai dengan prinsip 4T. Peraturan yang diterapkan dengan baik untuk meningkatkan disiplin pekerja dan adanya penghargaan kepada tenaga kerja yang berprestasi adalah cara untuk meningkatkan kualitas kerja yang lebih baik.

\section{Defisiensi Unsur Hara Tanaman}

Pengamatan defisiensi unsur hara tanaman kelapa sawit diamati secara visual dengan memperhatikan gejala-gelaja defisiensi tanaman yang dapat dilihat melalui kondisi daun, batang, dan pelepah namun gejala defisiensi paling banyak dapat dilihat dari daun. Faktor yang mempengaruhi defisiensi adalah pelaksanaan pemupukan yang tidak tepat waktu.Pemupukan dilakukan kurang memperhatikan konsep tepat waktu yang berkaitan dengan kondisi curah hujan. Pemupukan dilaksanakan saat curah hujan tinggi yang menyebabkan pupuk banyak yang hilang terbawa aliran air (Run -off), akibatnya pupuk tidak terserap dengan optimal sehingga tanaman banyak yang mengalami defisiensi unsur hara.

Tabel 9. Pengamatan gejala defesiensi hara kebun SBHE

\begin{tabular}{cccccccc}
\hline Ulangan & $\begin{array}{c}\text { E Pokok } \\
\text { diamati } \\
\text { (pohon) }\end{array}$ & $\begin{array}{c}\text { S Pokok } \\
\text { defisiensi } \\
\text { (pohon) }\end{array}$ & & \multicolumn{3}{c}{ Defisiensi Hara (pohon) } \\
\hline & & & $\mathrm{N}$ & $\mathrm{P}$ & $\mathrm{K}$ & $\mathrm{Mg}$ & $\mathrm{B}$ \\
\hline & 68 & 46 & 12 & 6 & 8 & 11 & 9 \\
2 & 68 & 38 & 15 & 3 & 3 & 7 & 10 \\
3 & 68 & 52 & 14 & 9 & 4 & 12 & 13 \\
\hline Total & 204 & 136 & 41 & 18 & 15 & 30 & 32 \\
\hline $\begin{array}{l}\text { Rata-rata } \\
\%\end{array}$ & & 66.7 & $13.67 \pm 1.57$ & $6 \pm 3$ & $5 \pm 2.64$ & $10 \pm 2.64$ & $10.67 \pm 2.08$ \\
\end{tabular}

Sumber: Hasil pengamatan lapangan (2013)

Pengamatan pada Tabel 9 menunjukkan bahwa dari 204 pokok yang diamati, 136 pokok mengalami defisiensi dengan persentase $20.1 \%$ mengalami defisiensi unsur $\mathrm{N}, 12.7 \%$ defisiensi unsur hara $\mathrm{B}, 8.8 \%$ defisiensi unsur hara $\mathrm{P}, 7.4 \%$ defisiensi unsur $\mathrm{K}$, dan $14.7 \%$ defisiensi unsur 
Mg. Pengamatan defisiensi unsur hara secara visual merupakan pendukung dan alternatif untuk melihat status unsur hara secara langsung, tidak bersifat mutlak hasilnya karena bersifat subjek. Penentuan dosis unsur hara dan status hara yang paling tepat adalah dengan analisis daun dan tanah dari laboratorium yang telah sesuai standar operational.

\section{KESIMPULAN}

Kegiatan magang di kebun SBHE banyak memberikan ilmu dan pengetahuan terkait budidaya kebun kelapa sawit yang meliputi kegiatan perawatan hingga panen. Kegiatan magang juga mampu membentuk sikap dan meningkatkan softskill saat penulis diberikan tanggungjawab manajerial dalam pengawasan tenaga kerja sehingga hal ini menjadi pengalaman penting bagi penulis untuk memasuki dunia kerja.

Pengamatan khusus terkait konsep 4 tepat pemupukan, ditemukan beberapa kendala di lapangan yaitu pelaksanaan konsep tepat waktu belum terlaksana dengan baik dan beberapa fasilitas kebun yang kurang memadai. Konsep tepat waktu di kebun SBHE dilakukan sepanjang tahun dan tidak memperhatikan kondisi curah hujan yang tinggi, saat curah hujan tinggi sebaiknya tidak dilakukan pemupukan karena dapat menyebabkan pupuk hilang tebawa aliran air dan tidak dapat terserap optimal oleh tanaman. Hal ini juga menyebabkan ketidakefisienan biaya. Fasilitas kebun seperti collection road (CR) dan main road (MR) yang rusak mempengaruhi pelaksanaan waktu kegiatan pemupukan hingga siang hari dan kondisi cuaca yang panas juga dapat menyebabkan bobot pupuk menyusut. Oleh karena itu, diharapkan adanya manajemen drainase yang baik di titik rawan MR dan CR agar lintasan tidak rusak ketika hujan. Karung pupuk juga banyak yang sobek dan berakibat bobot pupuk berkurang. Pemeriksaan rutin dan penggantian terhadap karung pupuk yang sobek penting dilakukan agar mengurangi losses pupuk.

\section{DAFTAR PUSTAKA}

[BPS] Badan Pusat Statistik. 2013. Produktivitas kelapa sawit tahun 2012. Tersedia pada:http://www.bps.go.id/tab_sub/view. php?kat $=3 \&$ tabel $=1 \&$ daftar=1\&id_subye $\mathrm{k}=54 \&$ notab $=2$ [diunduh 2013 Januari 5].
Chandra W. 2012. Studi pemupukan kelapa sawit (Elaeis guineensis Jacq.) pada tanaman menghasilkan (TM) di perkebunan bangun koling estate, PT Windu Nabatindo Abadi, Bumitama Gunajaya Agro Grup, Kotawaringin Timur, Kalimantan Tengah. [skripsi]. Bogor (ID): Institut Pertanian Bogor.

[Ditjen Perkebunan] Direktorat Jendral Perkebunan. 2013. Perkembangan luas areal perkebunan 2008-2013. Tersedia pada: http://ditjenbun.deptan.go.id/ tinymcpuk/ gambar/file/Luas _Areal_Estimasi_2013.pdf [diunduh 2013 Agustus 14].

[Ditjen Perkebunan] Direktorat Jendral Perkebunan. 2013. Perkembangan volume dan nilai ekspor komoditas primer perkebunan tahun 2008-2013. Tersedia pada: http://ditjenbun.deptan.go.id/berita294-ekspor-triwulan-i-tahun-2013.html [diunduh 2013 Agustus 14].

Lubis AU. 1992. Kelapa Sawit (Elaeis guinensis Jacquin) di Indonesia. Medan (ID): Pusat Penelitian Perkebunan Marihat Bandar Kuala. Marihat Ulu. 435 hal.

Pahan I. 2010. Panduan Lengkap Kelapa Sawit, Manajemen Agribisnis dari Hulu hingga Hilir. Jakarta (ID): Penebar Swadaya.

Prihutami ND. 2011. Analisis faktor penentu produksi tandan buah segar (TBS) tanaman kelapa sawit (Elaeis guineensis Jacq.) di Sungai Bahaur Estate (SBHE), PT Bumitama Gunajaya Agro (PT BGA), Wilayah VI Metro Cempaga, Kota Waringin Timur, Kalimantan Tengah. [skripsi]. Bogor(ID): Institut Pertanian Bogor.

Sastrosayono S. 2003. Budidaya Kelapa Sawit. Jakarta (ID): Agro Media Pustaka.

Setyamidjaja D. 2006. Kelapa Sawit: Teknik Budidaya, Panen, dan Pengolahan. Yogyakarta (ID): Kanisius.

Winarna, W Darmosarkoro dan ES Sutarta. 2003. Teknologi pemupukan tanaman kelapa sawit. Pusat Penelitian Kelapa Sawit. 